\title{
G23 エ夕ノール拡散火炎の消炎及び着火特性に関する数値解析
}

Numerical study of Extinction and Ignition Properties in Ethanol Diffusion Flame

○学 柏田 太志(大分大学大学院) 学 田尼 隆之(大分大学大学院) 正 田上 公俊(大分大学)

Hiroshi KASHIWADA, Takayuki TAJIRI, Kimitoshi TANOUE

Department of Engineering, Oita University

Key Words : Ethanol, Diffusion Flame, Extinction, Ignition

\section{1. 緒言}

現在の内燃機関技術には，地球環境問題とエネルギ一資源 枯渴問題から低公害な代替燃料の利用と高効率な燃焼技術の 開発が求められている. 石油代替燃料として注目されている エタノール $\left(\mathrm{C}_{2} \mathrm{H}_{5} \mathrm{OH}\right)$ は植物や木材から生成が可能なバイオ マスであるため，カーボンニュートラルな特徵を有する環境 調和型のエネルギ一資源としてその役割が強調されており， これまで，拡散火炎の消炎，着火に関するSeiser ら ${ }^{(1)}$, Holley ら ${ }^{(2)}$ の研究等，いくつかの研究が行われてきた。消炎特性は 燃料の高温酸化反応を, 着火特性は燃料の低・中温酸化反応 を体現した現象であるため，反応機構・燃焼モデルの構築及 び検証のための重要な基礎デー夕となる.そこで本研究では， 詳細化学反応機構を用いた対向流火炎モデルの数值解析によ り，大気压での $\mathrm{C}_{2} \mathrm{H}_{5} \mathrm{OH}$ の着火，消炎特性を調べ，対向流バ 一ナを用いた実験と比較することで，既存の化学反応機構の 検証を行う。

\section{2. 数値計算手法}

本研究では, 着火・消炎に関する数值計算手法として西岡 らが開発した 1 次元対向流火炎の計算コード(3)を使用した。 本研究では本コードを用いて Flame-Controlling Continuation methodにより消炎および自着火条件を特定した。また，火炎 温度の算出のための平衡計算には Reynolds などによって開発 された STANJAN に基づくEQUIL ${ }^{(4)}$ を,さらに，本研究で使 用した各熱物性值および輸送係数は $\mathrm{CHEMKIN}^{(4)}$ から算出し た.

本研究で使用した化学反応機構を表 1 に示す.それぞれSan Diego $^{(5)}$, Fischer et al. ${ }^{(6)}$, Marinov ${ }^{(7)}$ の反応機構（以下，それぞ れSDG05, FDC00, MRN99 と記す）である.

Table 1 Kinetic mechanisms used to simulate

\begin{tabular}{lcc}
\hline Mechanism & Species & Reactions \\
\hline \hline SDG05 $^{(5)}$ & 46 & 235 \\
FDC00 $^{(6)}$ & 81 & 359 \\
MRN99 $^{(7)}$ & 57 & 383 \\
\hline
\end{tabular}

モデルとする対向流バーナの概略図を図 1 に示す。対向流 バーナ上下のノズルから燃料と酸化剂を噴出しバーナの中央 部によどみ面を設置し，よどみ面近傍に伸張のある火炎を形 成すると考える.この際, 火炎伸張は次式から求める.

$$
a_{2}=2\left|V_{2}\right| / L\left(1+\left|V_{1}\right| \sqrt{\rho_{1}} /\left|V_{2}\right| \sqrt{\rho_{2}}\right) \quad\left(\mathrm{s}^{-1}\right)
$$

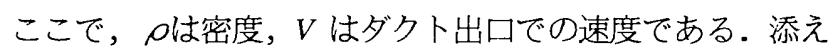
字 1,2 は燃料と酸化剂それぞれを示す. $L$ はバ一ナ間隔であ り, 消炎時 $8 \mathrm{~mm}$, 着火時 $10 \mathrm{~mm}$ とした. 本研究では, よどみ 平面が両ダクト間の中央付近に形成されるように，両ダクト 出口での流体の運動量を以下のように等しくした。

$\rho_{1} V_{1}^{2}=\rho_{2} V_{2}^{2}$

拡散燃焼場において混合層 (Mixing layer) 内の相対的な火 炎位置は以下のstoichiometric mixture fraction, $Z_{\mathrm{st}}$ により表すこ
とができる。

$$
Z_{s t}=\left(1+Y_{F, 1} W_{O} v_{O} / Y_{O 2.2} W_{F} v_{F}\right)^{-1}
$$

ここで $W$ は分子量, $v$ は量論比のモル数である. 添字 $\mathrm{O}$, Fは，酸化剤と燃料それそれの物理量を示す。

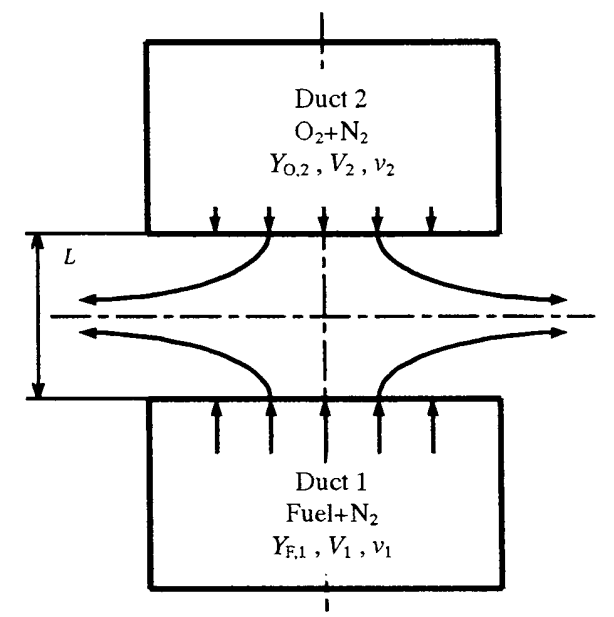

Fig. 1 Schematic illustration of counterflow configuration

\section{3. 計算結果及び考察}

\section{1 消炎に及ほす平衡温度の影響}

まず，本研究では酸化剂に空気 $\left(Y_{\mathrm{O} 2,2}=0.233\right)$ を用い，燃料 の質量濃度 $Y_{\mathrm{F}}$ を変化させた場合の消炎特性を調べた。

図 2 の(a)に燃料の質量濃度 $Y_{\mathrm{F}}$ と, 消炎時の火炎伸張率 $a_{2, \mathrm{E}}$ の実験結果を計算結果とともに示し,(b)に平衡温度 $T_{\mathrm{eq}}$ と消炎 時の火炎伸張率 $a_{2, \mathrm{E}}$ を示す.

図 2 の(a)の計算結果と実験結果を比較すると，定量的，定性 的共に燃料の全ての反応機構は実験結果をよく再現している. また, 図 2 の(b)では平衡温度 $T_{\mathrm{eq}}$ は消炎時の火炎伸張 $a_{2, \mathrm{E}}$ 従い上 昇しており,このグラフの傾向により消炎時の火炎伸張 $a_{2, \mathrm{E}}$ の増 加に従って耐消炎特性が向上することが分かる. 従って燃料の 質量分率 $Y_{\mathrm{F}, 1}$ が増加することにより平衡温度 $T_{\mathrm{eq}}$ が増加し, 酸化 反応がより早く進むことが分かる．よって燃燒がより完全燃焼 に近づき, 燃焼における未燃の損失が減る為, 消炎時の火炎伸 張率 $a_{2, \mathrm{E}}$ が増加する，つまり耐消炎特性が向上するものと考えら れる.

\section{2 消炎に及ぼす火炎構造の影響}

本研究では燃料にエ夕ノール $\left(\mathrm{C}_{2} \mathrm{H}_{5} \mathrm{OH}\right)$ を用いて平衡温度 $T_{\mathrm{eq}}$ を一定にし, 火炎構造 $Z_{\mathrm{st}}$ を変化させた場合の消炎特性を 調べた. 図 2 に平衡温度 $T_{\mathrm{eq}}=2050 \mathrm{~K}$ 一定の場合における消炎 時の火炎伸張率 $a_{2, \mathrm{E}}$ と火炎構造 $Z_{\mathrm{st}}$ の関係を実験結果と共に示 す.

図3にて解析結果と実験結果を比較すると，実験結果では 消炎時の火炎伸張率 $a_{2, \mathrm{E}}$ は火炎構造 $Z_{\mathrm{st}}$ に比例して増加してい るのに対し，解析結果では $a_{2, \mathrm{E}}$ が $Z_{\mathrm{st}}$ に対し最小值をとる点ま で減少してから増加しており，定性的に差異が見られる. 


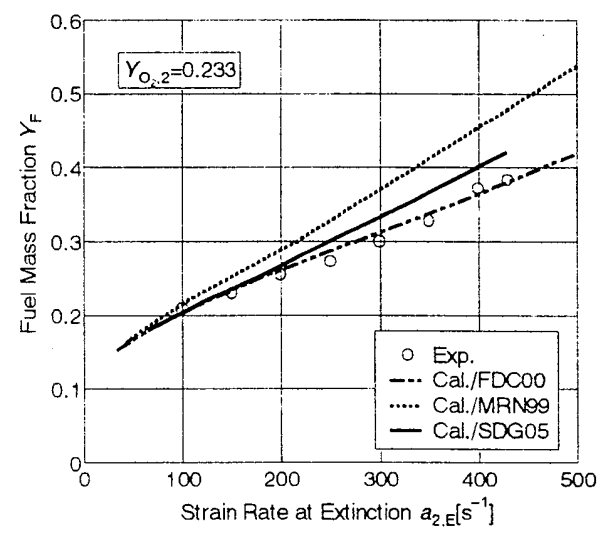

(a) Fuel Mass Fraction, as a function of the Strain Rate at Extinction

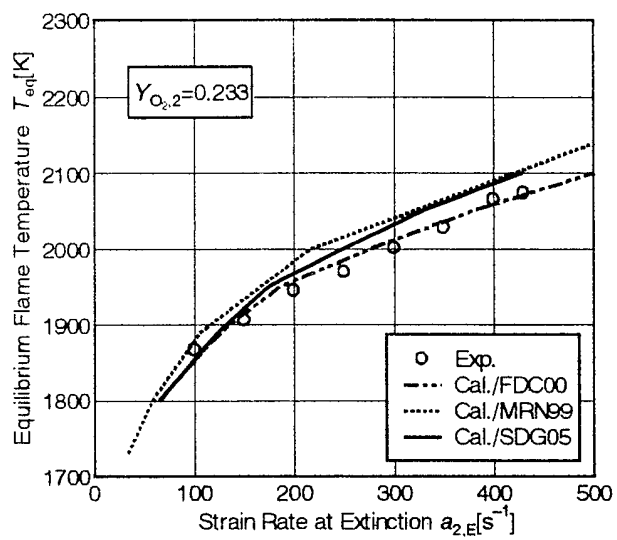

(b) Equilibrium flame temperature, as a function of Strain Rate at Extinctio

Fig. 2 Fuel Mass Fraction and Equilibrium Flame Temperature, in the fuel stream, as a function of the Strain Rate at Extinction

また, 火炎構造 $Z_{\mathrm{st}}$ が 0.3 付近における消炎時の火炎伸張 率 $a_{2, \mathrm{E}}$ では計算值と実験值は近い差であるが, $Z_{\mathrm{st}}$ が 0.70 付近 における $a_{2, \mathrm{E}}$ の差が大きいことが分かる.つまり $Z_{\mathrm{st}}$ が低い值 では，解析結果と実験結果には差が小さいが， $Z_{\mathrm{st}}$ が大きい領 域では定量的に大きい差があることが分かる。よって， $T_{\mathrm{eq}}$ $=2050 \mathrm{~K}$ 一定の条件において,いずれの反応機構においても解 析は定性的に実験を再現していない，従って数值計算に用い た 3 つの反応機構はいずれも今条件下において改善の余地が ある。

\section{3 着火に及ぼす酸化剂側温度の影響}

さらに本研究では燃料側のモル分率 $X_{\mathrm{f}}$ を一定にし, 酸化剂 側の温度を変化させた場合の着火特性を調べた。

図 4 に酸化剤側の温度 $T_{2,1}$ と自着火時の火炎伸張率 $a_{2, \mathrm{I}}$ の関 係を実験結果とともに示す. 図 4 から計算結果と実験結果を 比較すると，全ての反応機構において自着火時の火炎伸張率 の増加に伴い酸化剂側の温度は増加している.よって自着火 特性に及ぼす熱拡散及び物質拡散の影響が大きいことが分か る.

全ての反応機構において計算結果は実験結果より酸化剤 側の温度が全体的にやや低い値になったが, 差異は 4\%以下で ある．また酸化剤側の温度に比例して自着火時の火炎伸張率 も增加し定性的も全ての反応機構で一致している．よって本 研究の結果は全ての反応機構においてエタノールに関する中 低温酸化反応の再現性を有していることが分かる。

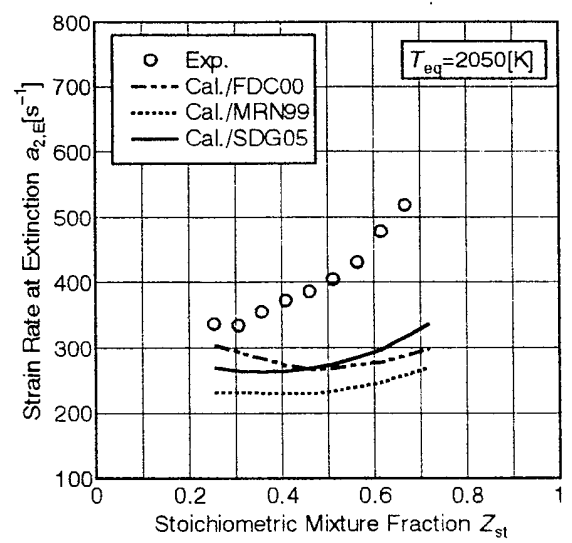

Fig. 3 Extinction Strain Rates, as a function of Stoichiometric Mixture Fraction, all with the same Equilibrium Temperature

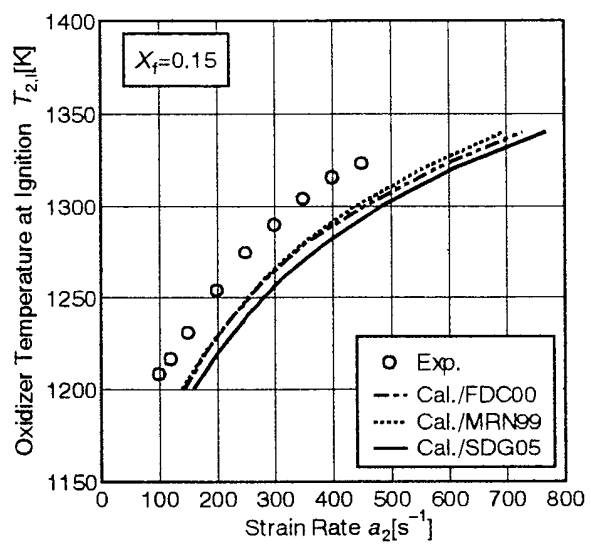

Fig.4 The temperature of the oxidizer stream at ignition, as a function of the strain rate

\section{4. 結論}

1. 酸化剂に空気（ $Y_{02,2}=0.233 ）$ を用いて, 平衡火炎温度 を変化させた場合の消炎特性を調べ実験結果と比較し たところ, 全ての反応機構において定量的, 定性的と もに一致していた。

2. $T_{\mathrm{eq}}=2050 \mathrm{~K}$ を固定し， $Z_{\mathrm{st}}$ を変化させた場合の消炎特性 調べたところ， $Z_{\mathrm{st}}$ が低い領域では定量的に差が小さく， $Z_{\text {st }}$ が高い領域では差が大きい. また実験と比較し定性 的に違いが見られ，定量的，定性的ともにこの条件下 において改善の余地がある。

3. 酸化剂側の $X_{\mathrm{f}}$ を一定とし, 酸化剂側の温度 $T_{2, \mathrm{I}}$ を変化 させた場合の着火特性を調べ実験結果と比較したとこ ろ, 全ての反応機構において定量的, 定性的共に一致 し, 中低温酸化反応の再現性を有していた。

\section{参考文献}

(1)Seiser, R., Humer, S., Seshadri, K. and Pucher, E., Proc. Combustion Inst. 31, p.1173-1180 (2007).

(2)Holley, A. T., Dong, Y., Andac, M. G. and Egolfopoulos, F. N., Combustion and Flame, 144, p.448-460 (2006)

(3)Nishioka, M., Law, C.K. and Takeno, T., Combustion and Flame. vol.104, 1996, p.328-342.

(4) Kee, R. J. Rupley, F. M. and Miller J. A. et al., CHEMKIN Collection, Release 3.7, Reaction Design, Inc., San Diego, CA, (2003)

(5)http://www.mae.ucsd.edu/ combustion/cermech/,Version 20051201 (6) Fischer, S. L., Dryer, F. L. and Curran, H. J., Int. J. Chem. Kinet. 32, p.713-740, 2000.

(7) Marinov, N. M., Int. J. Chem. Kinet., 31, p.183-220, 1999 